\title{
Evidence for enhanced rates of complement activation in serum from patients with newly diagnosed insulin-dependent diabetes mellitus exposed to rat islet cells and complement-dependent induction of islet cell apoptosis
}

\author{
E M Caraher, S J Conroy and P Newsholme \\ Department of Biochemistry, University College Dublin, Belfield, Dublin 4, Ireland \\ (Requests for offprints should be addressed to P Newsholme)
}

\begin{abstract}
In this paper we report the concentration of terminal complement complexes (TCCs, SC5b-9, an index of complement activation) in newly diagnosed insulindependent diabetes mellitus (IDDM) patient serum and normal human serum. In the nine patients studied, levels of serum soluble TCCs were approximately $1 \cdot 6$-fold higher than in sera obtained from normal control individuals. On incubation of rat islet cells with diluted serum $(10 \%, \mathrm{v} / \mathrm{v}$, concentration), complement activation was increased at a significantly faster rate and the total TCC concentration was significantly higher in culture medium containing IDDM patient serum than in medium containing control serum. The concentration of anti-(glutamic acid decarboxylase) autoantibodies in newly diagnosed IDDM patient serum was on average 60-fold higher than in normal human control serum.
\end{abstract}

IDDM patient serum $(10 \%, \mathrm{v} / \mathrm{v})$ induced apoptosis in islet cells, as determined by islet cell density changes and
DNA fragmentation patterns. However, serum from IDDM patients was not able to induce apoptosis of the cells when complement components $(\mathrm{C} 1 \mathrm{q}$ and $\mathrm{C} 3)$ or antibodies were depleted. In addition, glutamine and the potent antioxidant 1-pyrrolidinecarbodithioic acid partially reversed cell death induced by IDDM patient serum in a concentration-dependent manner. The ATP concentration in islet cells incubated for $24 \mathrm{~h}$ in the presence of diluted IDDM patient serum was reduced to $4 \cdot 4 \%$ of that observed in islet cells incubated in fetal calf serum or $7 \cdot 3 \%$ of that observed in islet cells incubated in normal human serum. On the basis of these observations, we suggest that the pathway of IDDM patient serum-induced islet cell apoptosis may involve antibody-dependent complement activation, free radical generation and a precipitous fall in ATP levels.

Journal of Endocrinology (1999) 162, 143-153

\section{Introduction}

The disease human insulin-dependent diabetes mellitus (IDDM) is characterised by $\beta$-cell death in the islets of Langerhans, resulting in a catastrophic loss of insulinsecretory capacity. Both cell-mediated and humoral immune mechanisms have been implicated in the pathogenesis of human IDDM (Eisenbarth 1986, Atkinson \& Maclaren 1994). Animal models of IDDM have demonstrated a role for T-lymphocytes in promoting $\beta$-cell death (Bach 1988, Castano \& Eisenbarth 1990). Human IDDM may also involve T-lymphocyte-induced $\beta$-cell death, as many pancreatic islets of newly diagnosed patients demonstrate insulitus with T-cell infiltration. However, Somoza et al. (1994) failed to detect any message for interleukin (IL)-1, tumour necrosis factor (TNF) or interferon (IFN) $-\gamma$ in pancreas from two patients with IDDM. O'Brien et al. (1997) have, in addition, reported that detectable levels of $\beta$-cell apoptosis occurred before lymphocytic infiltration of islets in the spontaneously diabetic NOD/Lt mouse. It is also known that autoantibody titres are increased in the serum of individuals with IDDM months to years before the clinical onset of diabetes (Bingley et al. 1994, Bonifacio et al. 1995). Botazzo et al. (1980) have reported that complement-fixing islet cell antibodies exist in the serum of IDDM patients and that they are a more reliable marker of pancreatic $\beta$-cell damage than conventional islet-cell antibodies. In addition, they reported deposition of the complement component C9 on some cells of pancreatic islets from a newly diagnosed IDDM patient (Bottazzo et al. 1985). However, it was not until recently that firm evidence emerged in support of a direct role for complement in islet cell death, indicating that complement-fixing islet cell antibodies in serum isolated from IDDM patients could trigger the assembly of terminal complement complexes 
(TCCs) on human islet cells (Radillo et al. 1996). As the pancreatic donor in the latter study was non-diabetic, strong evidence for complement activation initiating $\beta$-cell damage rather than being a reaction to it was provided. The mechanism of islet cell death was not assessed by Radillo et al.

The mechanism of $\beta$-cell death responsible for the development of IDDM in mouse models (NOD (O'Brien et al. 1997) or low-dose streptozotocin (O'Brien et al. 1996)) or in vitro studies with isolated rat cells ( $\mathrm{L}-1 \beta_{-}$, TNF- $\alpha$ - or IFN- $\gamma$-treated pancreatic islet or HIT $\beta$-cell line (Rabinovitch et al. 1994) or amylin-treated islet cells (Lorenzo et al. 1994)) have been described. All studies describe an apoptotic mechanism of $\beta$-cell death. The parameters measured include internucleosomal DNA cleavage, DNA strand breakage, cell volume decrease, condensation of nuclear chromatin and apoptotic body formation. In the study described here, we provide evidence for complement activation in serum from nine newly diagnosed IDDM patients, and assess biochemical and morphological parameters of apoptosis in rat islet cells exposed to newly diagnosed IDDM patient serum.

\section{Materials and Methods}

Unless otherwise stated all reagents were of analytical quality and were obtained from Sigma Chemical Company, Poole, Dorset, UK.

\section{Human serum samples}

Samples were obtained by venepuncture from nine consenting newly diagnosed IDDM patients and nine age-matched control subjects with no history of diabetes and confirmed normal glucose tolerance. Blood samples were collected in silicone-coated evacuated blood tubes and allowed to clot for $20 \mathrm{~min}$ at room temperature. The samples were then centrifuged at $400 \mathrm{~g}$ for $10 \mathrm{~min}$ and the supernatant removed for storage at $-70{ }^{\circ} \mathrm{C}$ until used.

The characteristics of the IDDM patient blood samples were as follows: seven male and two female patients, age 17-39 years. Serum samples were obtained between 3 days and 4 months after the diagnosis and at least $11 \mathrm{~h}$ after the last insulin injection. All patients were in a fasted state at the time the blood sample was taken.

\section{Anti-(glutamic acid decarboxylase (GAD)) assay}

Anti-GAD autoantibodies were measured in serum samples by using a 'Diaplets' anti-GAD kit supplied by Boehringer-Mannheim, according to the manufacturer's instructions.

\section{Removal of complement components C1q and C3 from serum}

Anti-C1q or anti-C3 antibodies (Sigma) were diluted in $10 \mathrm{mM}$ phosphate buffer containing $145 \mathrm{mM} \mathrm{NaCl}$, pH
$7 \cdot 2(44 \mathrm{mg} / \mathrm{ml}$ anti-human C1q or $38 \mathrm{mg} / \mathrm{ml}$ anti-human C3). A $100 \mu \mathrm{l}$ sample of diluted anti-C1q antibodies was added to columns $1-6$ of a 96-well microtitre plate, and $100 \mu \mathrm{l}$ of diluted anti-C3 antibodies to columns 7-12. After incubation at $4{ }^{\circ} \mathrm{C}$ overnight, the buffer was removed and the wells washed three times with $10 \mathrm{mM}$ phosphate buffer containing $500 \mathrm{mM} \mathrm{NaCl}$ and $0 \cdot 1 \%$

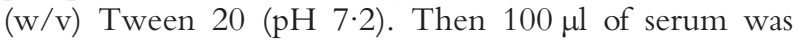
added to column 1 and the plate was incubated at room temperature for $40 \mathrm{~min}$. After this time, the serum samples were removed and transfered to column 2, where they were incubated for $40 \mathrm{~min}$ and then transfered to column 3 , and so on. By the time the serum samples had reached column 12, they were depleted of complement (C1q and C3) as assessed by cell viability studies.

Control plates were set up with $0 \cdot 1 \%$ BSA replacing anti-C1q and anti-C3 antibodies. The sera obtained from the control plates had similar complement-activation profiles to those not added to control plates.

\section{Isolation and culture of rat islets}

Male Wistar rats, 8-10 weeks old, were obtained from the Biomedical Facility, University College Dublin. Islet cells were obtained by collagenase digestion of the pancreas as previously described (Appels et al. 1989). Some $1 \times 10^{6}$ cells were seeded into each well of a 24-well plate in RPMI 1640 medium containing antibiotics and 10\% serum (human or fetal calf serum(FCS)). In some experiments (where indicated) RPMI medium initially depleted of both glucose and glutamine was used for cell culture, but with the subsequent addition of $0,1 \cdot 0,2 \cdot 0$ or $5 \cdot 0 \mathrm{mM}$ glutamine.

\section{Culture of cell lines}

The rat clonal $\beta$-cell line BRIN BD11 was kindly donated by Professor P Flatt, Unversity of Ulster, Coleraine, $\mathrm{N}$ Ireland and was cultured as previously described (McClenaghan et al.1996). The pig kidney epithelial cell line, LLC-DK1, was generously provided by Professor M Ryan, Department of Pharmacology, University College Dublin and was cultured as previously described (Hull et al. 1976).

Determination of SC5b-9 (TCC) formation in serum and culture medium from rat islet cells exposed to various serum types

Serum samples were obtained as described above and diluted for the SC5b-9 assay. Islet cells were prepared as previously described and plated at a density of $1 \times 10^{5}$ per well in a $24-$ well tissue culture plate; they were subsequently cultured with $10 \%(\mathrm{v} / \mathrm{v})$ human serum (IDDM patient or normal) or $10 \%$ FCS over a time period of up to $24 \mathrm{~h}$. SC5b-9 production was determined using an 
enzyme immunoassay kit (Quidel, San Diego, CA, USA) as follows. The microassay wells coated with a mouse monoclonal antibody specific for human SC5b-9 were rehydrated by incubation with $250 \mu \mathrm{l}$ wash solution (PBS, pH 7.4, containing $0 \cdot 05 \%$ Tween 20 and $0 \cdot 01 \%$ thiomersol) for $2 \mathrm{~min}$ at room temperature $\left(20-26{ }^{\circ} \mathrm{C}\right)$. After incubation, the wash buffer was removed and the wells blotted dry on absorbent paper. Then $100 \mu \mathrm{l}$ standards (human serum containing known amounts of SC5b-9) or appropriately diluted samples were added, followed by incubation at room temperature for $1 \mathrm{~h}$. After incubation, the wells were washed five times with wash buffer and blotted dry as before. Then $50 \mu$ l SC5b-9 conjugate (horseradish peroxidase-conjugated goat antibodies to antigens of SC5b-9 diluted in PBS containing protein stabilizers and $0 \cdot 01 \%$ thiomerosal) were added, followed by incubation for $1 \mathrm{~h}$ at room temperature. After this period the mixture was decanted and the wells were washed four or five times as before. Immediately after the wash procedure, $100 \mu \mathrm{l}$ substrate solution $(50 \mu \mathrm{l}$ of $0.7 \%$ 2,2'-azino-di-(3-ethylbenzthiazolinesulphonic acid) diammonium salt per $\mathrm{ml}$ of $0 \cdot 1 \mathrm{M}$ citrate buffer containing $0 \cdot 05 \% \mathrm{H}_{2} \mathrm{O}_{2}$ ) was added to each well. After $30 \mathrm{~min}$ incubation at room temperature, the reaction was terminated by the addition of $50 \mu \mathrm{l} 250 \mathrm{nM}$ oxalic acid to each well. The absorbance was determined at $405 \mathrm{~nm}$ within $1 \mathrm{~h}$.

\section{Percoll density-gradient centrifugation}

Percoll solutions $(1 \cdot 08,1 \cdot 078,1 \cdot 076,1 \cdot 074,1 \cdot 072,1 \cdot 07$, $1 \cdot 06 \mathrm{~g} / \mathrm{ml}$ ) were prepared as previously described (Cotter \& Martin 1996) and layered into an appropriate centrifuge tube. Islet cells (suspended in $2 \mathrm{ml}$ Percoll solution $(1.06 \mathrm{~g} / \mathrm{ml}))$ were carefully layered on top of the gradient before centrifugation at $400 \mathrm{~g}$ for $30 \mathrm{~min}$.

Detection of islet cell cytoplasmic histone-associated DNA fragments (mono- and oligo-nucleotides) by ELISA and DNA strand breaks by in situ nick translation

Islet cells were cultured in RPMI 1640 medium supplemented with $10 \%$ serum (IDDM patient, normal human or FCS). After 24 or $48 \mathrm{~h}$ the culture plate was centrifuged for $10 \mathrm{~min}$ at $200 \mathrm{~g}$. The supernatant was removed, and cell pellets were resuspended in lysis buffer, centrifuged to remove cell debris and the supernatant transfered to a prepared microtitre plate for determination of DNA fragments using a cell death detection ELISA kit (BoehringerMannheim) according to the manufacturer's instructions.

To detect DNA strand breaks in situ, rat islet cells were incubated in the presence of IDDM serum or normal human serum for $24 \mathrm{~h}$ and then acetone-fixed. Cells were subsequently washed and exposed to nick-translation mixture (Feshel et al. 1994). They were finally exposed to peroxidase-labelled avidin to allow immunocytochemical detection of biotin-labelled dUTP. Cells with strand breaks stained brown.

\section{Determination of cell viability}

Islet cell viability was assayed via exclusion of the vital dye, trypan blue, which is taken up by cells when loss of membrane integrity occurs. Cell viability of both islet cells and kidney epithelial cells was also assessed via cell lactate dehydrogenase content and agreed well with the trypan blue-exclusion studies.

\section{Determination of ATP concentration}

The bioluminescent somatic cell assay kit (Sigma) was used to determine ATP released from a suspension of islet cells after culture in the presence of 10\% IDDM patient serum, normal human serum or FCS. ATP concentration was determined in accordance with the manufacturer's instructions using a Turner luminometer.

\section{Statistical analysis}

The results are presented as mean \pm s.E.M. Groups of data were compared using unpaired Student's t-test where appropriate. Differences were considered significant if $P<0 \cdot 01$ or $P<0 \cdot 001$.

\section{Results}

SC5b-9 concentration in serum obtained from newly diagnosed IDDM patients and normal human control subjects and in serum diluted in cell culture medium and exposed to rat islet cells for up to $24 \mathrm{~h}$

Levels of soluble TCCs (SC5b-9) were determined in serum from both IDDM patients and non-diabetic control individuals. Nine newly diagnosed IDDM patients gave a blood sample between 3 days and 5 months after the initial diagnosis. The IDDM patients had a mean age of $26 \cdot 8 \pm 2 \cdot 4$ years (mean \pm s.E.M.). The TCC level in these individuals was $3.69 \pm 0.59 \mu \mathrm{g} / \mathrm{ml}$. Nine non-diabetic individuals (sex-matched) mean age $25 \cdot 8 \pm 1 \cdot 2$ years had a mean TCC concentration of $2 \cdot 28 \pm 0 \cdot 75 \mu \mathrm{g} / \mathrm{ml}$ (Fig. 1a). The difference in TCC concentration between IDDM and non-diabetic individuals was not significantly different $(0 \cdot 1<P<0 \cdot 2)$. However, exposure of rat pancreatic islet cells to $10 \%$ IDDM patient serum (from here on called IDDM serum) caused substantial activation of complement compared with cells incubated in the presence of normal human serum, resulting in a significantly higher TCC concentration in the medium of cells exposed to IDDM serum at all time points measured (Fig. 1b). In addition, significantly higher levels of TCC were found in 

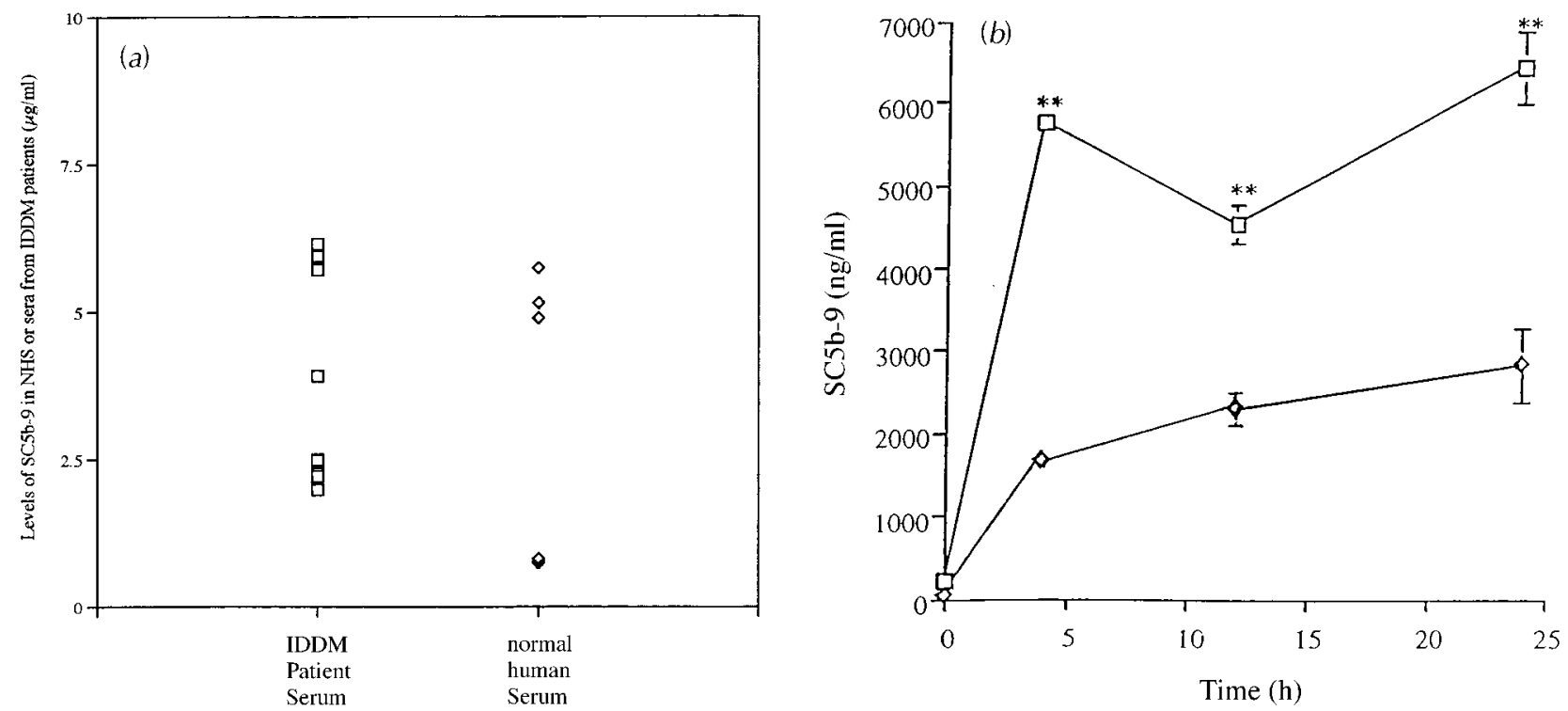

Figure 1 Determination of level of complement activation in human sera and islet cell incubation medium. Patient and normal human sera were obtained as described in the Materials and Methods section. (a) SC5b-9 was determined in diluted serum samples. $(b) 1 \times 10^{6}$ islet cells were incubated in the presence of $10 \%(\mathrm{v} / \mathrm{v})$ IDDM serum $(\square)$ or normal human serum (NHS) $(\diamond)$ for up to $24 \mathrm{~h}$. SC5b-9 concentrations were determined. They were significantly higher in medium containing IDDM serum than in medium containing normal human serum where indicated $\left({ }^{* *} P<0 \cdot 01\right)$.

medium supplemented with IDDM serum after exposure to the rat clonal $\beta$-cell line BRIN BD11 than in medium supplemented with normal human serum (Table 1). The concentration of TCC was not significantly elevated in culture medium containing IDDM serum above that observed in medium containing normal human serum when exposed to either of two unrelated cell types, the pig kidney epithelial cell line, LLC-DK1, or the murine resident peritoneal macrophage (Table 1).

\section{Anti-GAD concentration in newly diagnosed IDDM patient serum}

The presence of antibodies to GAD is an indication of an autoimmune process which, in the majority of cases, leads to IDDM. A positive test result with an anti-GAD concentration of $>32 \mathrm{ng} / \mathrm{ml}$ indicates manifest IDDM or an autoimmune process that is likely to lead to IDDM. Using a Boehringer-Mannheim 'Diaplets' assay kit,

Table 1 The concentration of SC5b-9 (TCC, Terminal Complement Complex) after $24 \mathrm{~h}$ in cell culture medium supplemented with either normal human or IDDM patient serum $(10 \%, v / v)$ was determined. P-values indicate the level of significant difference between TCC concentration in medium containing IDDM serum compared with medium containing normal human serum after $24 \mathrm{~h}$ of cell culture. Results are expressed as mean \pm S.E.M.

\begin{tabular}{|c|c|c|c|}
\hline & Serum type & $\begin{array}{l}\text { TCC formation after } 24 \mathrm{~h} \text { culture } \\
\text { (ng per } 1 \times 10^{6} \text { cells) }\end{array}$ & $P$ value \\
\hline $\begin{array}{l}\text { Cell type } \\
\text { Primary rat islets }\end{array}$ & $\begin{array}{l}\text { Normal human } \\
\text { IDDM patient }\end{array}$ & $\begin{array}{l}2838 \pm 450 \\
6424 \pm 435\end{array}$ & $<0 \cdot 01$ \\
\hline $\begin{array}{l}\text { BRIN BD11 rat } \\
\text { pancreatic } \beta \text {-cells }\end{array}$ & $\begin{array}{l}\text { Normal human } \\
\text { IDDM patient }\end{array}$ & $\begin{array}{l}3534 \pm 334 \\
6213 \pm 453\end{array}$ & $<0.01$ \\
\hline $\begin{array}{l}\text { LLC-DK1 pig kidney } \\
\text { epithelial cells }\end{array}$ & $\begin{array}{l}\text { Normal human } \\
\text { IDDM patient }\end{array}$ & $\begin{array}{l}1572 \pm 197 \\
1007 \pm 95\end{array}$ & $=0.031$ \\
\hline $\begin{array}{l}\text { Primary rat peritoneal } \\
\text { macrophages }\end{array}$ & $\begin{array}{l}\text { Normal human } \\
\text { IDDM patient }\end{array}$ & $\begin{array}{l}1930 \pm 83 \\
2233 \pm 232\end{array}$ & $>0 \cdot 05$ \\
\hline
\end{tabular}




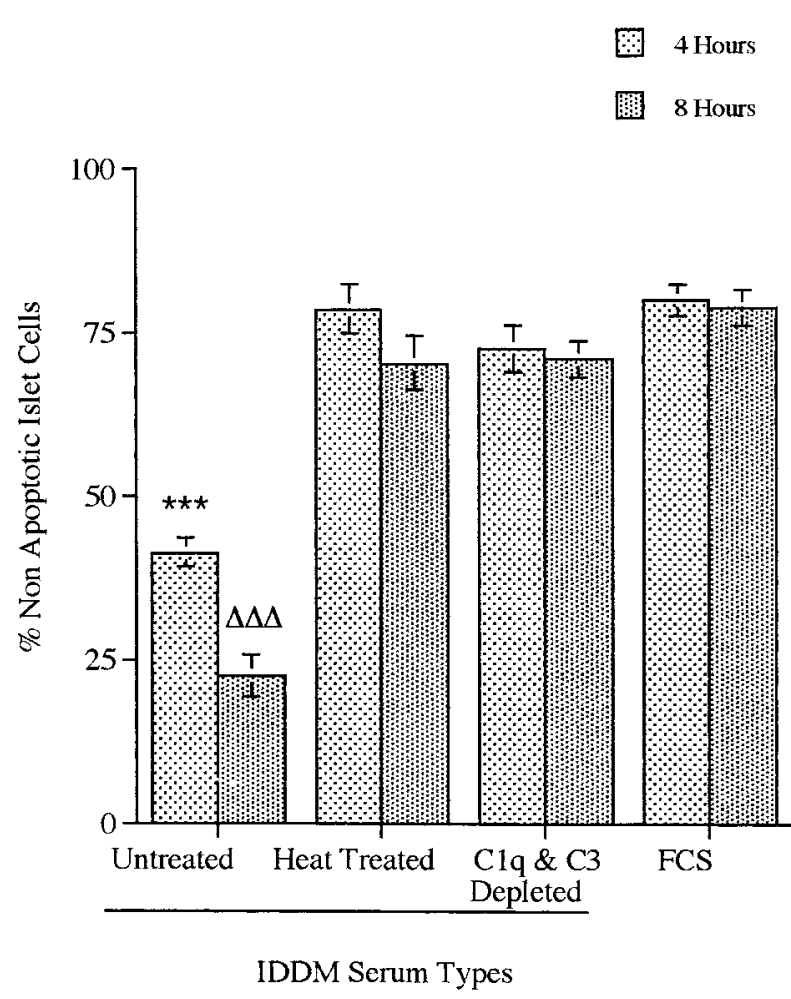

Figure 2 Determination of changes in islet cell buoyant density. Islet cells $\left(1 \times 10^{6}\right)$ were incubated in the presence of $10 \%(\mathrm{v} / \mathrm{v})$ IDDM serum, heat-treated IDDM serum, C1q- and C3-depleted IDDM serum or FCS for 4 or $8 \mathrm{~h}$. Islet cell buoyant density was then determined. The change in islet cell density was significantly different for cells incubated in IDDM serum from that in cells incubated in either heat-treated or C1q- and C3-depleted IDDM serum $\left({ }^{* *} P<.001\right.$, after $4 \mathrm{~h}$ incubation and ${ }^{{ }^{\Delta \Delta \Delta} P<0.001}$ after $8 \mathrm{~h}$ incubation).

we determined a mean anti-GAD concentration of $925 \cdot 6 \pm 190 \cdot 5 \mathrm{ng} / \mathrm{ml}$ in newly diagnosed IDDM patient serum $(n=15)$ which is approximately 60 -fold higher than that in normal human serum $(15 \cdot 4 \pm 1.5 \mathrm{ng} / \mathrm{ml} ; n=12)$.

Assessment of buoyant cell density after 4 or $8 \mathrm{~h}$ exposure to IDDM serum, complement-depleted IDDM serum, heat-treated IDDM serum, non-diabetic serum or FCS

As early apoptotic cells shrink, there is an increase in their buoyant cell density. They can be resolved from their non-apoptotic neighbours by centrifugation after layering on to a $1.06-1.08 \mathrm{~g} / \mathrm{ml}$ Percoll gradient (Appels et al. 1989). After centrifugation, non-apoptotic cells are found at the $1 \cdot 06 / 1.07 \mathrm{~g} / \mathrm{ml}$ interface, whereas the cells that form the pellet are apoptotic. Exposure of rat islets for 4 or $8 \mathrm{~h}$ to IDDM serum resulted in a large change in buoyant cell density, with approximately $60 \%$ and $80 \%$ of cells detected as apoptotic after $4 \mathrm{~h}$ and $8 \mathrm{~h}$ respectively (Fig. 2). The cells detected in the non-apoptotic layer were not insulin containing as determined by immunofluorescence and immunostaining (insulin) methodologies. Depletion of IDDM serum complement components $\mathrm{C} 1 \mathrm{q}$ and $\mathrm{C} 3$ or heat treatment (denaturing heat-labile complement components) resulted in a large decrease in the amount of apoptotic cells detected (approximately 30\% after 4 and 8 h; Fig. 2). The latter value was close to the level of apoptosis detected in cells exposed to normal human serum or FCS.

Measurement of DNA fragmentation in rat islet cells exposed to IDDM serum, heat-treated IDDM serum, normal human serum or FCS

One of the hallmarks of apoptotic death is early DNA fragmentation. It is possible to detect histone-associated DNA fragments (mono- and oligo-nucleosomes) released from the fragmenting nuclei of cells undergoing apoptosis, by an ELISA method. We determined that there was an approximately $600 \%$ increase in DNA fragmentation in rat islet cells exposed to IDDM serum for $24 \mathrm{~h}$ compared with cells exposed to heat-treated IDDM serum or normal human serum (Fig. 3a). Similar results were obtained for rat islet cells exposed to $10 \%$ serum for $48 \mathrm{~h}$.

To detect DNA strand breaks in situ, we incubated rat islet cells in the presence of IDDM serum for $24 \mathrm{~h}$ and then acetone-fixed the cells. Cells were subsequently washed and exposed to nick-translation mixture (Feshel et al. 1994). They were finally exposed to peroxidaselabelled avidin to allow immunocytochemical detection of biotin-labelled dUTP. Those with strand breaks stained brown. There was an approximately twofold increase in cells containing DNA strand breaks after $24 \mathrm{~h}$ incubation in IDDM serum compared with cells incubated in normal human serum (Fig. 3b).

Cell viability in cells exposed to newly diagnosed IDDM patient serum, heat-treated IDDM serum, normal human serum or FCS, assessed by trypan blue exclusion

One of the major distinguishing morphological features of cell death is a loss of membrane integrity which may be detected by failure to exclude trypan blue. Both necrotic and apoptotic cells undergoing secondary necrosis will fail to exclude trypan blue. When rat islet cells were exposed to IDDM serum for $24 \mathrm{~h}$, approximately $65 \cdot 0 \pm 2 \cdot 9 \%$ remained viable, whereas only $50 \cdot 0 \pm 1 \cdot 7 \%$ were viable after $48 \mathrm{~h}$ (Fig. 4). The number of viable cells remaining after exposure to $10 \%$ heat-treated IDDM serum or normal human serum for $24 \mathrm{~h}$ was $89 \cdot 0 \pm 2 \cdot 3 \%$ and $80 \cdot 8 \pm 5 \cdot 8 \%$ respectively (Fig. 4 ), whereas viability after $48 \mathrm{~h}$ incubation was determined to be $82 \cdot 6 \pm 4 \cdot 1 \%$ or $72 \cdot 1 \pm 2 \cdot 9 \%$ respectively (Fig. 4 ).

The difference in loss of viability between cells cultured in untreated IDDM serum compared with those cultured in heat-treated IDDM serum, normal human serum or 

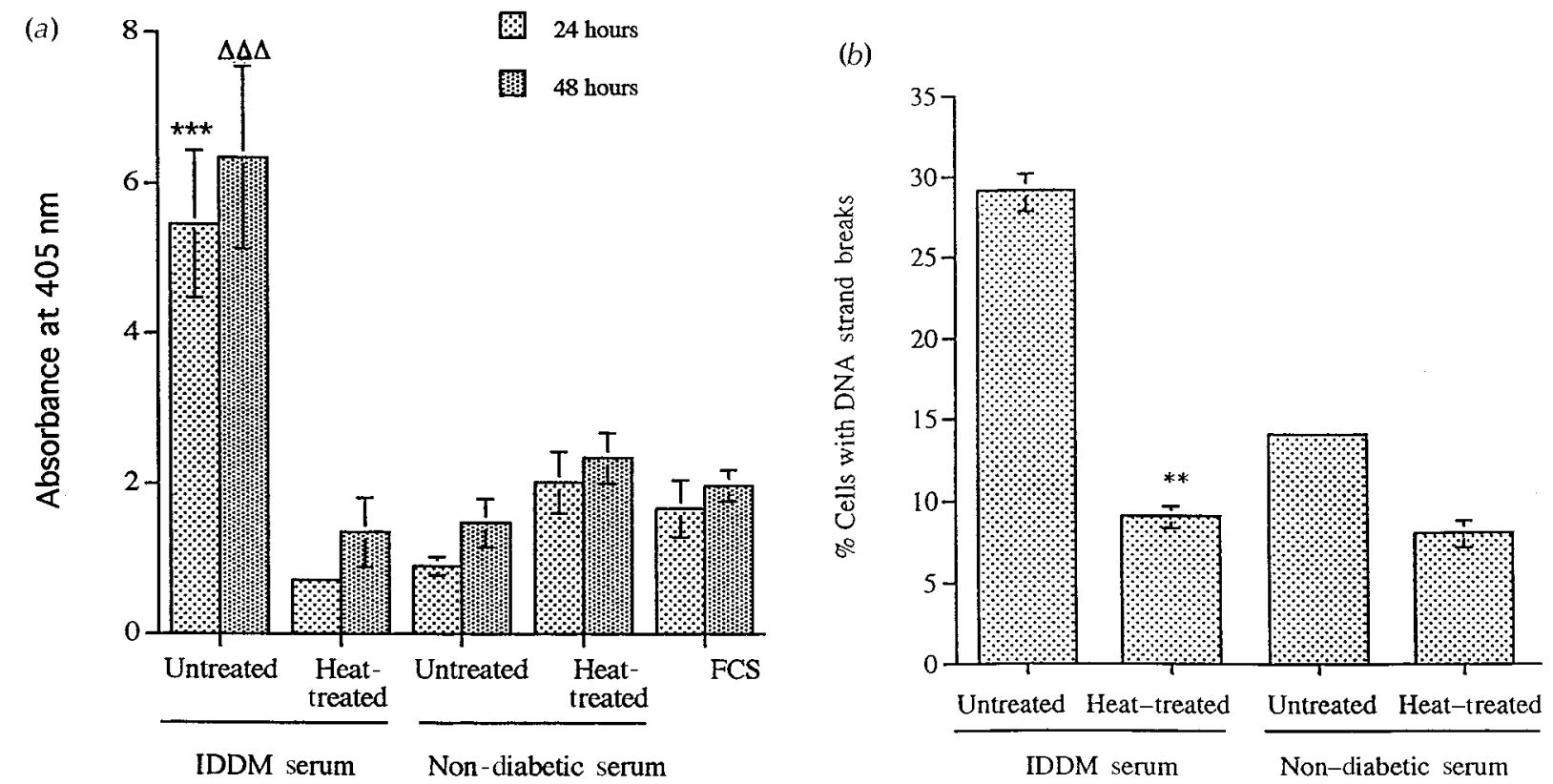

Figure 3 Measurement of islet cell DNA fragmentation and single-cell DNA strand breaks. (a) Islet cells were incubated in the presence of $10 \%(\mathrm{v} / \mathrm{v})$ IDDM, heat-treated IDDM or normal human serum, or FCS for 24 or $48 \mathrm{~h}$. DNA fragmentation was determined using a Boehringer-Mannheim Cell death detection ELISA. Islet cells cultured in untreated IDDM serum had a significantly higher level of fragmented DNA compared with those cells cultured in heat-treated IDDM serum or normal human serum ${ }^{* * *} P<0 \cdot 001$ after $24 \mathrm{~h}$ incubation and ${ }^{\Delta \Delta \Delta} P<0.001$ after $48 \mathrm{~h}$ incubation). (b) To detect DNA strand breaks in situ, rat islet cells were incubated in the presence of IDDM serum or normal human serum for $24 \mathrm{~h}$ and then acetone-fixed. Cells were subsequently washed and exposed to nick-translation mixture (Feshel et al. 1994). They were finally exposed to peroxidase-labelled avidin to allow immunocytochemical detection of biotin-labelled dUTP. Cells with strand breaks stained brown. ( ${ }^{*} P<0 \cdot 01$ after $24 \mathrm{~h}$ incubation compared with untreated IDDM serum).

FCS was significant $(P<0 \cdot 01)$ after 24 and $48 \mathrm{~h}$ (Fig. 4). However, loss in viability can be both IDDM serumdependent and IDDM serum-independent, as illustrated by the results presented in Fig. 4 (compare loss of viability of cells cultured in untreated IDDM serum, normal human serum and FCS). The degree of non-specific serum-induced cell death increased substantially after $72 \mathrm{~h}$, so that there was no difference in loss of viability of cells cultured in IDDM serum or normal human serum after $96 \mathrm{~h}$ of culture (results not shown).

The viability of an unrelated cell type, the pig kidney epithelial cell line, LLC-DK1, was reduced to $87 \cdot 4 \pm 2 \cdot 4 \%$ after $24 \mathrm{~h}$ incubation in the presence of IDDM serum. In addition, the viability of murine resident peritoneal macrophages was not significantly reduced by $24 \mathrm{~h}$ of culture in IDDM serum compared with culture in normal human serum (results not shown). The loss of viability of islet cells cultured in IDDM serum is thus cell specific.

Effect of depletion of complement components C1q and C3 or Protein A immunoprecipitation of immunoglobulins, from IDDM patient serum on cell viability

To determine the importance of complement pathway activation or the presence of immunoglobulins of the $\operatorname{IgG}$ class to the loss of islet cell viability induced by IDDM serum, we depleted serum of either complement components $\mathrm{C} 1 \mathrm{q}$ and $\mathrm{C} 3$ or $\operatorname{IgG}$ as described in the Materials and Methods section. The substantial loss of islet cell viability observed on exposure of islet cells to IDDM serum (compared with normal human serum or FCS) was abolished when $\mathrm{C} 1 \mathrm{q}$ and $\mathrm{C} 3$ were removed from the serum (Fig. 5a) or IgG was removed from the serum (Fig. 5b) after both 24 and $48 \mathrm{~h}$ of incubation.

Effect of the antioxidant 1-pyrrolidinecarbodithioic acid, ammonium salt (PDTC) on islet cell viability after exposure to $I L-1 \beta$ or IDDM serum

IL-1 $\beta$ can potently induce death in islet cells: $10 \mathrm{ng} / \mathrm{ml}$ reduced islet cell viability from $83 \cdot 1 \pm 3 \cdot 5 \%$ to $40 \cdot 1 \pm 3 \cdot 5 \%$. The cytotoxic effect of $10 \mathrm{ng} / \mathrm{ml}$ IL- $1 \beta$ can be partially reversed by incubation of the islet cells with the potent antioxidant PDTC; the recovery occurs in a concentration-dependent manner, reaching a value of $63.4 \pm 2.9 \%$ in the presence of $500 \mu \mathrm{M}$ PDTC (Fig. 6, top). When rat islet cells were incubated with IDDM serum for $48 \mathrm{~h}$, the substantial loss of viability $(55 \cdot 8 \pm 3 \cdot 5 \%)$ could also be partially reversed, in a 
24 Hours

48 Hours

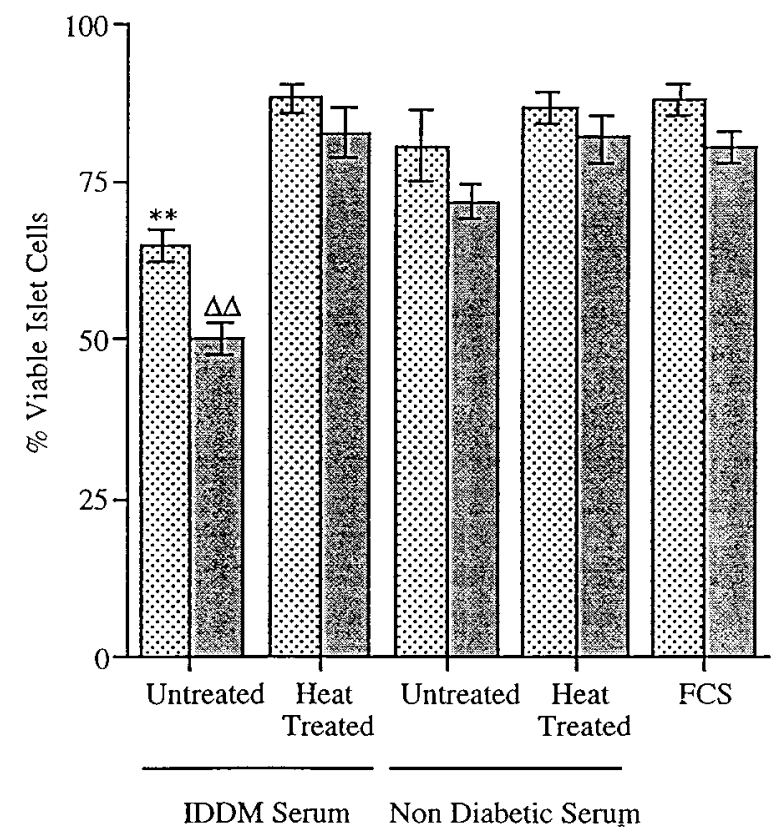

Figure 4 Effect of incubation in various serum types on islet cell viability. Islet cells were incubated in the presence of $10 \%(\mathrm{v} / \mathrm{v})$ IDDM, heat-treated IDDM or normal human serum for 24 or $48 \mathrm{~h}$. Cell viability was determined by trypan blue exclusion. Islet cells cultured in untreated IDDM serum had a significantly lower viability than those cells cultured in heat-treated IDDM serum or normal human serum $\left({ }^{*} P<0 \cdot 01\right.$ after $24 \mathrm{~h}$ incubation and ${ }^{\Delta \Delta} P<0.01$ after $48 \mathrm{~h}$ incubation).

concentration-dependent manner, by incubation in the presence of PDTC (to $72 \cdot 7 \pm 2 \cdot 3 \%$; Fig. 6, bottom).

\section{Effect of glutamine concentration on islet cell viability after exposure to IDDM serum, normal human serum or FCS}

When rat islet cells were incubated in the presence of IDDM serum for 24 or $48 \mathrm{~h}$, the substantial loss of viability (compared with control serum) could be reversed by incubation in the presence of $5 \mathrm{mM}$ glutamine $(50 \%$ viability after $48 \mathrm{~h}$ incubation was increased to $76 \cdot 2 \pm 1 \cdot 7 \%$ in the presence of $5 \mathrm{mM}$ glutamine; Fig. 7). The addition of $5 \mathrm{mM}$ glutamine had no effect on viability of cells incubated in heat-treated IDDM serum, normal human serum or FCS (results not shown).

Additional experiments demonstrated that the substantial loss of cell viability (compared with control serum) of rat islets incubated in the presence of IDDM serum for $48 \mathrm{~h}$ could be partially reversed by incubation in the presence of $1 \mu \mathrm{M}$ nifedipine, an L-type $\mathrm{Ca}^{2+}$ channel antagonist (from $54 \cdot 1 \%$ in the absence to $62.8 \%$ in the presence of $1 \mu \mathrm{M}$ nifedipine after $48 \mathrm{~h}$ incubation; results not shown).

Measurement of cell ATP concentration after exposure to
IDDM serum, normal human serum or FCS

Islet cells were incubated in the presence of IDDM serum, normal human serum or FCS for 24 and $48 \mathrm{~h}$. ATP concentration in cells exposed to IDDM serum was reduced to $4 \cdot 4 \%$ of that found in cells incubated in FCS or $7 \cdot 3 \%$ of that found in cells incubated in normal human serum after $24 \mathrm{~h}$ (Table 2). A similar precipitous fall in ATP concentration was observed in cells incubated in IDDM serum for $48 \mathrm{~h}$ (Table 2).

\section{Discussion}

Evidence for complement activation, e.g. increased circulating levels of $\mathrm{C} 4 \mathrm{a}$ and $\mathrm{C} 3 \mathrm{a}$ but no detectable change in TCC concentration in serum from IDDM patients compared with serum samples from patients with noninsulin-dependent diabetes mellitus and age-matched controls, has been previously reported (Bergamaschini et al. 1991). However, the IDDM patients used in the latter study had been diagnosed some years earlier (mean 3 years, range 2-23 years), thus it is probable that reduced circulating autoantibody and activated complement components in these patients may explain the low levels reported (Bergamaschini et al. 1991) compared with those reported here for newly diagnosed patients. Other reports have shown that complement-fixing islet cell antibodies are increased in the serum of IDDM individuals (Bonifacio et al. 1995, Dobersen et al. 1980). The previous studies may have been unable to detect significant levels of activated complement in serum from IDDM patients, because of lack of availablity or poor specificity of antibodies used for the TCC ELISA. Here we report that levels of serum soluble TCCs are approximately 1.6-fold higher in serum from newly diagnosed IDDM patients than age-matched non-diabetic control individuals. Complement activation in IDDM individuals may initiate $\beta$-cell damage rather than occur in response to damage caused by other immune mechanisms, thus a number of studies have attempted to demonstrate complementmediated $\beta$-cell cytotoxicity after exposure to IDDM patient serum. IDDM patient serum was found to be cytotoxic to rat islet cells (Feshel et al. 1994), hamster islet cells (Rittenhouse et al. 1980) and cloned rat islet cells (Eisenbarth et al. 1981) at levels significantly above those found when cells were incubated in serum from patients with non-insulin-dependent diabetes mellitus or normal human serum. However, one report has shown that normal human serum (heat-inactivated) can cause similar levels of cytotoxicity to newly diagnosed IDDM serum in 


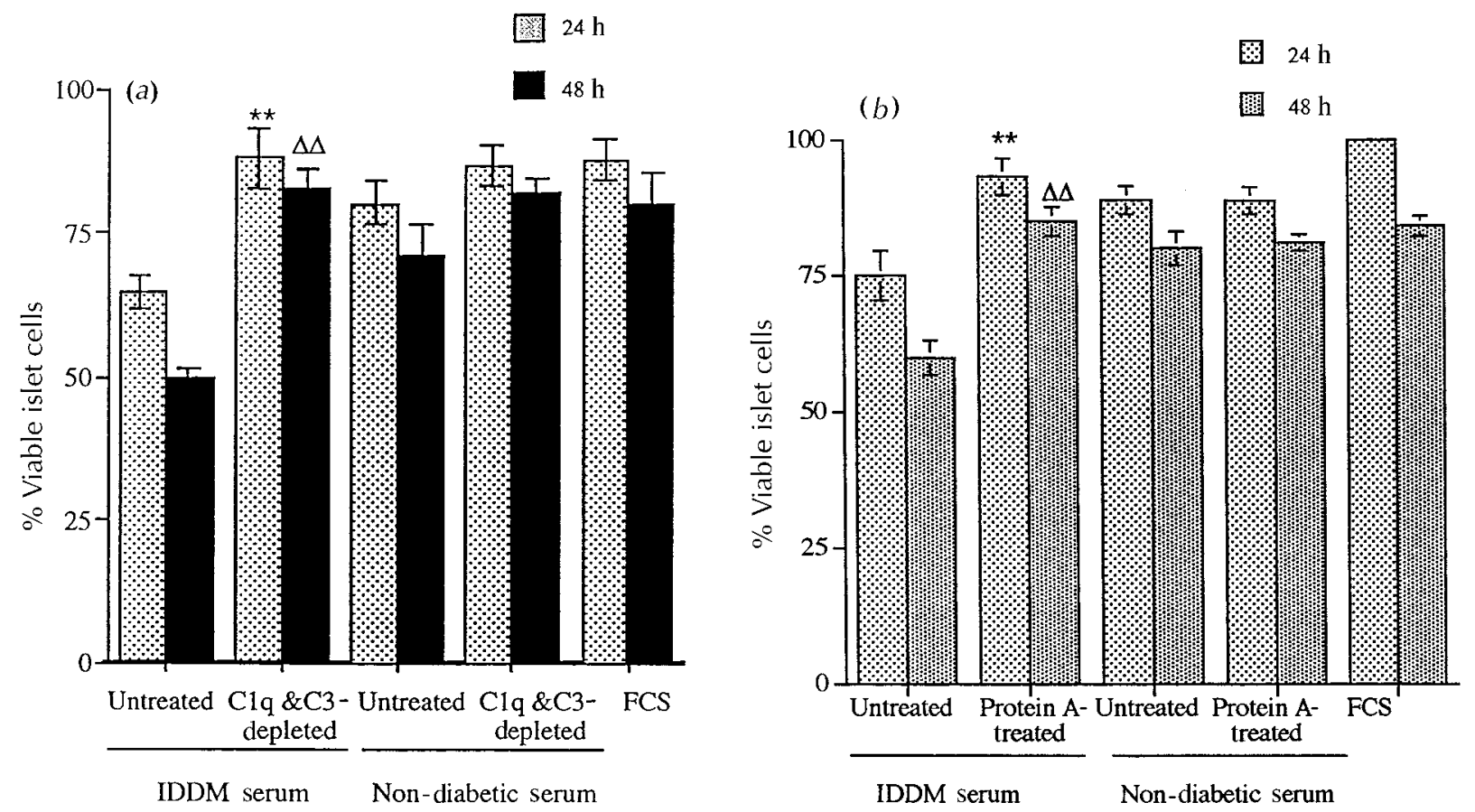

Figure 5 Effect of incubation in standard serum, complement-depleted IDDM serum, Protein A-treated serum, normal human serum or FCS on islet cell viability. (a) Islet cells were incubated in the presence of 10\% (v/v) IDDM, C1q-and C3-depleted IDDM serum or normal human serum for 24 or $48 \mathrm{~h}$. Cell viability was determined by trypan blue exclusion. Islet cells cultured in C1q-and C3-depleted IDDM serum had significantly greater viability than those cells cultured in untreated IDDM serum $\left({ }^{* \star} P<0 \cdot 01\right.$ after $24 \mathrm{~h}$ incubation and ${ }^{\Delta \Delta} P<0.01$ after $48 \mathrm{~h}$ incubation). (b) Islet cells were incubated in the presence of $10 \%(\mathrm{v} / \mathrm{v})$ IDDM, Protein A-treated IDDM serum or normal human serum for 24 or $48 \mathrm{~h}$. Cell viability was determined by trypan blue exclusion. Islet cells cultured in Protein A-treated IDDM serum had significantly greater viability than those cells cultured in untreated IDDM serum ${ }^{* *} P<0 \cdot 01$ after $24 \mathrm{~h}$ incubation and ${ }^{\Delta \Delta} P<0 \cdot 01$ after $48 \mathrm{~h}$ incubation).

the presence of rabbit serum (Cavender et al. 1986). The problems associated with heterologous activation of complement may have contributed to the latter results. However, more recently, Radillo et al. (1996) have reported that the cytotoxic activity of IDDM serum towards human pancreatic islets is dependent on TCC formation. In this study, we have shown that complement activation occurs in culture medium supplemented with IDDM or control serum exposed to rat islet cells, but the level of TCC in medium supplemented with serum from IDDM patients was significantly higher at all time points measured. In addition, we have reported that the level of TCC in cell culture medium after exposure to the clonal $\beta$-cell line, BRIN BD11, was significantly higher in medium supplemented with IDDM serum than in normal human serum (Table 1; Conroy et al. 1998). The level of TCC in medium supplemented with IDDM serum was not significantly different from medium supplemented with normal human serum when exposed to either primary murine macrophages or the pig kidney epithelial cell line, LLC-DK1 (Table 1). We have demonstrated that there is a relatively high concentration of autoantibodies in IDDM patient serum (45-fold above normal human serum) and we speculate that elevated complement activation occurs after the autoantibodies have bound to their specific autoantigen target on the $\beta$-cell surface.

The mechanism of complement-mediated cytotoxicity in islets exposed to IDDM serum has only been alluded to in one recent study, where the process of apoptosis was implied on the basis of DNA fragmentation patterns (Juntti-Berggren et al. 1993). In this study we have provided evidence that, on exposure to islet cells, complement is activated at a faster rate in IDDM serum than in non-diabetic control serum, and that complement is responsible for initiating apoptosis in islet cells. Our cell viability assays also demonstrate that both complement and antibody components in serum are involved in the process of cell death, probably via classical complement pathway activation. The mechanism by which apoptosis is initiated by complement activation remains unknown. However, evidence is provided in this paper that oxidant generation may be involved, as loss of viability may be partially reversed by addition of the antioxidant, PDTC. As IL-1 $\beta-$ induced cell death may also be partially reversed by PDTC, the pathways of complement- and IL- $1 \beta$-induced death may share common steps. IL-1 $\beta$ is known to upregulate the expression of inducible nitric oxide synthase in HIT-T15 cells (Eizirik et al. 1992) as well as 

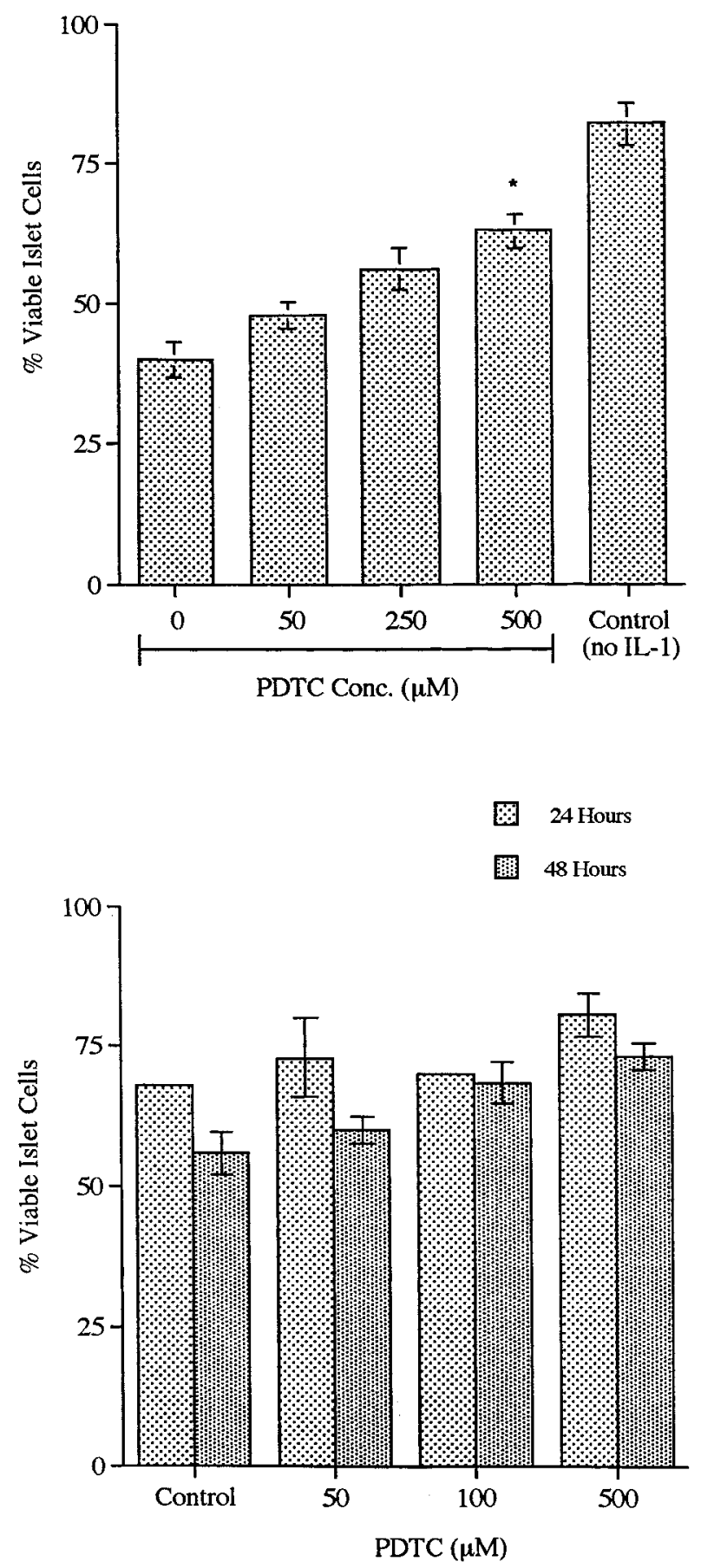

Figure 6 Effect of the antioxidant PDTC on IL-1 $\beta$ - or IDDM serum-induced islet cell cytotoxicity. Top, $1 \times 10^{6}$ islet cells were incubated with $10 \%(\mathrm{v} / \mathrm{v}) \mathrm{FCS}, 10 \mathrm{ng} / \mathrm{ml} \mathrm{IL-} 1 \beta$ and various concentrations of PDTC for $24 \mathrm{~h}$. PDTC significantly inhibited IL-1 $\beta$-induced cytotoxicity at $500 \mu \mathrm{M}\left({ }^{*} P<0 \cdot 01\right.$ after $24 \mathrm{~h}$ incubation). Cell viability was determined by trypan blue exclusion. Bottom, $1 \times 10^{6}$ islet cells were incubated with $10 \%(\mathrm{v} / \mathrm{v})$ IDDM serum and various concentrations of PDTC for 24 and $48 \mathrm{~h}$. Cell viability was determined by trypan blue exclusion.

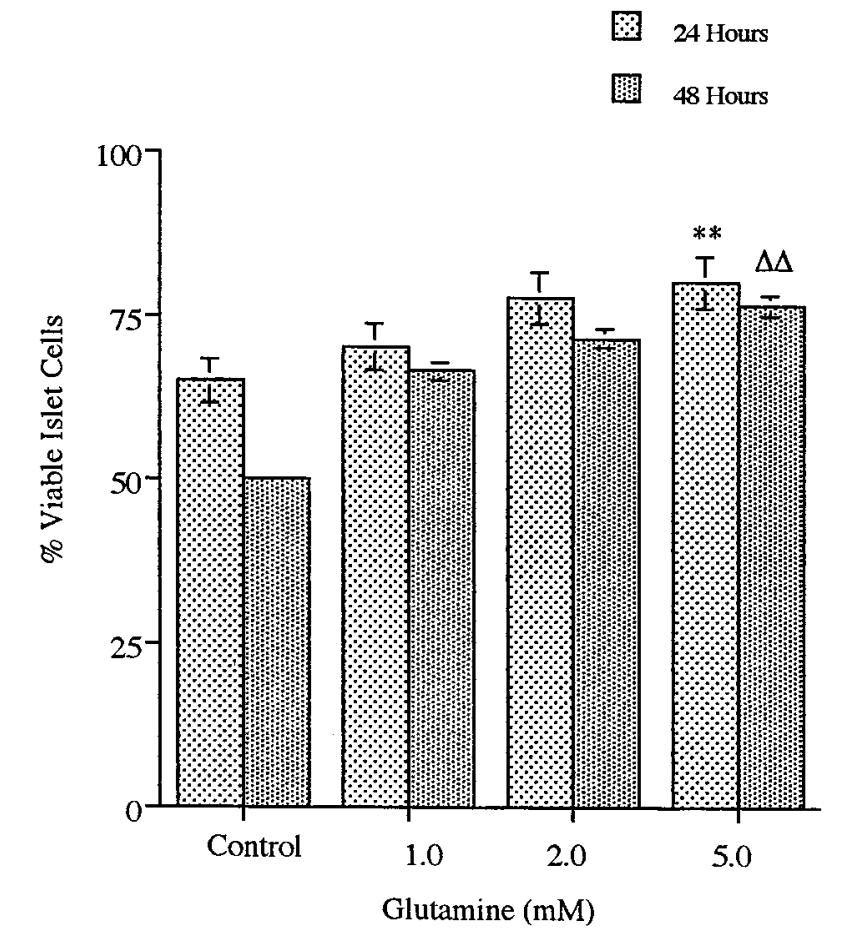

Figure 7 Effect of extracellular L-glutamine concentration on IDDM serum-induced islet cell cytotoxicity. Islet cells $\left(1 \times 10^{6}\right)$ were cultured in glucose- and glutamine-deficient RPMI medium (Gibco) and were additionally incubated with $10 \%$ (v/v) IDDM serum and various concentrations of L-glutamine for 24 and $48 \mathrm{~h}$. Cell viability was determined by trypan blue exclusion. L-Glutamine significantly inhibited IDDM serum-induced cytotoxicity at $5 \mathrm{mM}$ $\left({ }^{* *} P<0 \cdot 01\right.$ after $24 \mathrm{~h}$ incubation and ${ }^{\Delta \Delta} P<0 \cdot 01$ after $48 \mathrm{~h}$ incubation).

stimulating NO production in mouse pancreatic islets (Welsh \& Sandler 1992) and rat pancreatic islets (Corbett et al. 1991). IL-1 $\beta$ also causes significant DNA damage in islet cells and HIT-T15 cells via NO generation (Delaney et al. 1993, Kaneto et al. 1995). Thus NO generation may

Table 2 ATP concentration in rat islet cells exposed to 10\% IDDM patient, normal human serum or FCS for 24 or $48 \mathrm{~h}$. Islet cells were cultured in RPMI 1640 medium supplemented with 10\% $(\mathrm{v} / \mathrm{v})$ IDDM or normal human serum or FCS. After 24 or $48 \mathrm{~h}$ ATP concentration was determined using a bioluminescent somatic cell assay kit (Sigma), according to the manufacturer's instructions. ATP concentation as $\mathrm{fmol} / 100000$ cells

\section{Serum type}

IDDM (untreated)

IDDM (heat treated)

Normal human (untreated)

Normal human (heat treated) FCS

\begin{tabular}{|c|c|}
\hline \multicolumn{2}{|c|}{ ATP concentration } \\
\hline $24 \mathrm{~h}$ & $48 \mathrm{~h}$ \\
\hline $0 \cdot 11$ & 0.07 \\
\hline $0 \cdot 90$ & $0 \cdot 86$ \\
\hline $1 \cdot 50$ & $1 \cdot 32$ \\
\hline $1 \cdot 43$ & $1 \cdot 21$ \\
\hline $2 \cdot 50$ & 1.90 \\
\hline
\end{tabular}


play a key role in IL-1 $\beta$-stimulated cell death. The antioxidant PDTC may act upstream of NFKB, i.e. before transcription of inducible nitric oxide synthase, as oxidants can be potent stimulators of the transcription factor (Schreck et al. 1992), or may act by scavenging NO radicals after translation of inducible nitric oxide synthase. The mechanism of complement-stimulated islet-cell death and the mechanism described above for IL- $1 \beta$-stimulated death may or may not share common components.

We have determined that provision of L-glutamine can be cytoprotective to islet cells exposed to IDDM serum. L-Glutamine can be utilized at high rates by islet cells (Malaisse et al. 1982) and its metabolism may be connected to the pathways controlling insulin secretion. It is possible that oxidation of L-glutamine can elevate the ATP/ADP ratio sufficiently to block a catastrophic depletion of ATP which may occur after DNA damage and activation of poly(ADP-ribose) polymerase (Okamoto 1992). We have demonstrated that ATP levels in islet cells incubated in the presence of IDDM serum are reduced to $4.4 \%$ of those in islet cells incubated in FCS or $7 \cdot 3 \%$ of those in islets incubated in normal human serum after $24 \mathrm{~h}$ (Table 2). The L-type $\mathrm{Ca}^{2+}$ channel antagonist, nifedipine, partially reversed the cytotoxic effects of IDDM serum on islet cells (results not shown), suggesting that $\mathrm{Ca}^{2+}$ influx may contribute to cell death-promoting pathways. Our data suggesting that activation of L-type $\mathrm{Ca}^{2+}$ channels may be important in the mechanism of death support those of Juntti-Berggren et al. (1993) who provided evidence for the involvement of L-type $\mathrm{Ca}^{2+}$ channels in the pathway of IDDM serum-induced death of RINm5F cells.

The involvement of autoantibodies and complement in $\beta$-cell apoptosis in vivo may occur downstream of a switch in activated T-lymphocyte stimulation of B-lymphocytes such that the B-lymphocytes subsequently produce complement-fixing anti- $\beta$-cell antibodies. The relatively low level of complement activation that we report here in the serum of newly diagnosed IDDM patients (the level of $5 \mu \mathrm{g} / \mathrm{ml}$ TCC in IDDM serum represents about $2 \%$ of total circulating C5 to C9 components) suggests a 'lowgrade' assault in vivo that results in a relatively slow rate of apoptosis, which must exceed the rate of $\beta$-cell regeneration. This hypothesis would fit with the known slow pathogenesis of most types of IDDM, from initial $\beta$-cell destruction to clinical diagnosis. Previous experiments in which autoantibodies were injected into healthy animals without subsequent development of diabetes may indicate that the initial autoantibodies produced in diabetes-prone animals are non-complement-fixing. These autoantibodies would not be able to precipitate diabetes in recipient animals. A switch in autoantibody isotype in response to a developmental/environmental stimulus may result in circulating complement-fixing autoantibodies being produced from B-lymphocytes, leading to enhanced rates of $\beta$-cell destruction. We speculate that complement-fixing autoantibodies will be present at high concentrations at the time of diagnosis.

Although cytotoxic T-lymphocytes and macrophages may play a significant role in late $\beta$-cell destruction, a paper by Radillo et al. (1996) has described detectable levels of $\beta$-cell apoptosis before lymphocytic infiltration of islets in the NOD/Lt mouse, suggesting that humoral factors may be important early on in disease pathogenesis.

\section{Acknowledgements}

We thank Professor Victoria Kolb-Bachofen, University of Dusseldorf, Germany, and members of her laboratory for their help and advice on the methodology of rat islet cell preparation and in situ measurement of islet cell DNA fragmentation. We also thank Dr Richard Firth and Sister Deidre Creegan of the Diabetic Clinic, Mater Hospital, Dublin and Dr Paul Byrne, Department of Biochemistry, University College Dublin for obtaining serum samples from consenting newly diagnosed IDDM patients. We gratefully acknowledge financial support from the Diabetes Federation of Ireland (Phil Vizzard Research Grant 1994-1997).

\section{References}

Appels B, Burkart V, Kantwerk-Funke G, Funda J, Kolb-Bachofen V \& Kolb H 1989 Spontaneous cytotoxicity of macrophages against cultured pancreatic islet cells. Journal of Immunology 142 3803-3808.

Atkinson MA \& Maclaren NK 1994 The pathogenesis of insulindependent diabetes mellitus. New England Journal of Medicine 331 $1428-1436$.

Bach J-F 1988 Mechanisms of autoimmunity in insulin-dependent diabetes mellitus. Clinical and Experimental Immunology 72 1-8.

Bergamaschini L, Gardinali M, Poli M, Lorini, Bosi, Emanuele \& Agostoni A 1991 Complent activation in diabetes mellitus. Journal of Clinical and Laboratory Immunology 35 121-127.

Bingley PJ, Christie MR, Bonifacio E, Bonafanti R, Shattock M, Fonte M-T, Bottazzo G-F \& Gale EAM 1994 Combined analysis of autoantibodies improves prediction of IDDM in islet cell antibody-positive relatives. Diabetes 43 1304-1310.

Bonifacio E, Genovese S, Braghi S, Bazzigaluppi E, Lampasona V, Bingley PJ, Rogge L, Pastore MR, Bognetti E, Bottazzo G-F, Gale EAM \& Bosi E 1995 Islet autoantibody markers in IDDM: risk assessment strategies yielding high sensitivity. Diabetologia $\mathbf{3 8}$ $816-822$.

Bottazzo G-F, Dean BM, Gorsuch AN, Cudworth AG \& Doniach D 1980 Complement-fixing islet-cell antibodies in type 1 diabetes. Possible monitors of active beta-cell damage. Lancet i 668-672.

Bottazzo G-F, Dean BM, McNally JM, MacKay EH, Swift PGF \& Gamble DR 1985 In situ characterization of autoimmune phenomena and expression of HLA molecules in the pancreas in diabetic insulitus. New England Journal of Medicine 313 353-360.

Castano L \& Eisenbarth GS 1990 Type 1 diabetes: a chronic autoimmune disease of human, mouse, and rat. Annual Review of Immunology 8 647-679.

Cavender DE, Virji MA \& Holze-Joost S 1986 Presence of complement-dependent cytotoxic activity against clonally-derived rat islet tumour cells in sera from type-1 (insulin-dependent) diabetic patients and control subjects. Diabetologia 29 616-622. 
Conroy SJ, Abdel-Wahab YHA, Caraher EM, Byrne PM, Flatt PR \& Newsholme P 1999 Evidence for complement-dependent and independent inhibition of insulin secretion from clonal $\beta$-cells incubated in the presence of newly diagnosed IDDM patient sera. Clinical Science (In press).

Corbett JA, Lancaster JR, Sweetland MA \& McDaniel ML 1991 Interleukin-1 $\beta$ induced formation of EPR-detectable iron-nitrosyl complexes in Islets of Langerhans. Journal of Biological Chemistry 266 21351-21354.

Cotter TG \& Martin SJ 1996 In Techniques in Apoptosis, pp 18-20. London: Portland Press.

Delaney CA, Green MHL, Lowe JE \& Green IC 1993 Endogenous nitric oxide induced by interleukin- $1 \beta$ in rat islets of Langerhans and HIT-T15 cells causes significant DNA damage as measured by the 'comet' assay. FEBS Letters 333 291-295.

Dobersen MJ, Scharff JE, Ginsberg-Fellner F \& Notkins L 1980 Cytotoxic autoantibodies to beta-cells in the serum of patients with insulin dependent diabetes mellitus. New England Journal of Medicine 303 1493-1498.

Eisenbarth GS 1986 Type 1 diabetes mellitus: a chronic autoimmune disease. New England Journal of Medicine 315 1360-1368.

Eisenbarth GS, Morris MA \& Scearce RM 1981 Cytotoxic antibodies to cloned rat islet cells in serum of patients with diabetes mellitus. Journal of Clinical Investigation 67 403-408.

Eizirik DL, Cagliero E, Bjorklund A \& Welsh N 1992 Interleukin-1ß induces the expression of an isoform of nitric oxide synthase in insulin-producing cells which is similar to that observed in activated macrophages. FEBS Letters 308 249-252.

Feshel K, Kroncke KD, Kolb H \& Kolb-Bachofen V 1994 In situ nick-translation detects focal apoptosis in thymuses of glucocorticoid and lipopolysaccharide treated mice. Journal of Histochemistry and Cytochemistry 42 613-616.

Hull RN, Cherry WR \& Weaver GW 1996 The origin and characteristics of a pig kidney cell strain LLC-PK. In Vitro 12 670-677.

Juntti-Berggren L, Larsson O, Rorsman P, Ammala C, Bokvist K, Wahlander K, Nicotera P, Dypbukt J, Orrenius S, Hallberg A \& Berggren P-O 1993 Increased activity of L-type $\mathrm{Ca}^{2+}$ channels exposed to serum from patients with type-1 diabetes. Science $\mathbf{2 6 1}$ 86-90.

Kaneto H, Fujii J, Seo HG, Suzuki K, Matsuoka T-A, Nakamura M, Tatsumi H, Yamasaki Y, Kamada T \& Taniguchi N 1995 Apoptotic cell death triggered by nitric oxide in pancreatic $\beta$-cells. Diabetes 44 733-738.

Lorenzo A, Razzaboni B, Weir GC \& Yankner BA 1994 Pancreatic islet cell toxicity of amylin associated with type-2 diabetes mellitus. Nature 368 756-760.

McClenaghan NH, Barnett CR, O'Harte FPM \& Flatt PR 1996 Characterization of a novel glucose-responsive insulin-secreting cell line BRIN BD11 produced by electrofusion. Diabetes $\mathbf{4 5}$ $1132-1140$.
Malaisse WJ, Sener A, Malaisse-Lagae F, Welsh M, Matthews DE, Bier DM \& Hellerstrom C 1982 The stimulation-secretion coupling of amino acid-induced insulin release. Journal of Biological Chemistry 257 8731-8737.

O’Brien BA, Harmon BV, Cameron DP \& Allan DJ 1996 Beta-cell apoptosis is responsible for the development of IDDM in the multiple low-dose streptozotocin model. Journal of Pathology 178 176-181.

O’Brien BA, Harmon BV, Cameron DP \& Allan DJ 1997 Apoptosis is the mode of $\beta$-cell death responsible for the development of IDDM in the nonobese diabetic (NOD) mouse. Diabetes 46 750-759.

Okamoto H 1992 Mechanisms of destruction of insulin-secretion cells. In Nutrient Regulation of Insulin Secretion, pp 387-406. Ed PR Flatt. London: Portland Press.

Rabinovitch A, Suarez-Pinzon WL, Shi Y, Morgan AR \& Bleackley RC 1994 DNA fragmentation is an early event in cytokine-induced islet beta-cell destruction. Diabetologia 37 733-738

Radillo O, Nocera A, Leprini A, Barocci S, Mollnes TE, Pocecco M, Pausa M, Valente U, Betterle C \& Tedesco F 1996 Complementfixing islet cell antibodies in Type 1 diabetes can trigger the assembly of the terminal complement complex on human islet cells and are potentially cytotoxic. Clinical Immunology and Immunopathology 79 217-223.

Rittenhouse HG, Oxender DL, Pek S \& Ar D 1980 Complementmediated cytotoxicity effects on pancreatic islets with sera from diabetic patients. Diabetes 29 317-322.

Schreck R, Meier B, Mannel DN, Droge W \& Baeuerle PA 1992 Dithiocarbamates as potent inhibitors of nuclear factor $\mathrm{\kappa B}$ activation in intact cells. Journal of Experimental Medicine $\mathbf{1 7 5}$ 1181-1194.

Somoza N, Vargas F, Roura-Mir C, Vives-Pi M, Fernandez-Figueras MT, Ariza A, Gomis R, Bragado R, Marti M, Jaraquemada D \& Pujol-Borrell R 1994 Pancreas in recent onset insulin-dependent diabetes mellitus: changes in HLA, adhesion molecules and autoantigens, restricted $\mathrm{T}$-cell receptor $\mathrm{V} \beta$ usage and cytokine profile. Journal of Immunology 153 1360-1377.

Welsh N \& Sandler S 1992 Interleukin-1 $\beta$ induces nitric oxide production and inhibits the activity of aconitase without decreasing glucose oxidation rates in isolated mouse pancreatic islets. Biochemical and Biophysical Research Communications 182 $333-340$.

Received 22 July 1998

Revised manuscript received 22 December 1998 Accepted 11 February 1999 